виховання / Л. М. Масол // Педагогіка i психологія. - 2001. - № 3-4. - С. 69-79. 9. Сластенин В. А. Макаренко как теоретик воспитания / В. А. Сластенин // Педагогическое образование и наука. - 2008. - № 3. - С. 5-7. 10. Хархан Г. Д. Виховання сім'янина в педагогічній спадщині А.С. Макаренка / Г. Д. Хархан // Соціальна педагогіка: теорія та практика. - 2010. - № 1. - С. 66-71. 11. Ярмаченко Н. Д. Педагогическая деятельность и творческое наследие А. С. Макаренко : [книга для учителя] / Н. Д. Ярмаченко. - Київ : Рад. школа, 1989. - 191 с.

УДК: 378. 011. 3-051: 80

Дмитро Левчук

\title{
ФОРМУВАННЯ МОВЛЕННЕВОЇ КУЛЬТУРИ МАЙБУТНІХ УЧИТЕЛІВ ФІЛОЛОГІЧНИХ СПЕЦІАЛЬНОСТЕЙ ЯК НАУКОВО-ПЕДАГОГІЧНА ПРОБЛЕМА
}

Левчук Д. В. Формування мовленнєвої культури майбутніх учителів філологічних спеціальностей як науково-педагогічна проблема.

У статті розглядається проблема формування мовленнєвої культури майбутніх учителів філологічних спеціальностей, з'ясовується сутність поняття «культура мовлення». Звертається увага на основні функції педагогічного мовлення та проблеми студентів, з якими вони стикаються у процесі мовлення.

Ключові слова: культура мовлення, мова, мовленнєва культура, функції мовлення, майбутні вчителі філологічних спеціальностей.

Левчук Д. В. Формирование культуры речи будущих учителей филологических специальностей как научно-педагогическая проблема.

В статье рассматривается проблема формирования культуры речи будущих учителей филологических специальностей, выясняется сущность понятия «культура речи». Обращается внимание на основные функции педагогической речи и проблемы студентов, с которыми они сталкиваются в процессе речи.

Ключевые слова: культура речи, язык, речевая культура, функции речи, будущие учителя филологических специальностей.

Levchuk D. V. Speech culture formation of future teachers of philology as a scientific and pedagogical problem.

The article deals with the problem of speech culture formation of future teachers of philologycal specialities; the concept of the term "culture of speech" has been defined. Attention to the basic functions of pedagogical speech and educational problems which students face during speech process is drawn.

Key words: speech culture, language, speech function, future teachers of philology.

Розбудова національної системи освіти в умовах становлення України як самостійної незалежної держави з урахуванням кардинальних змін в усіх галузях суспільного життя, історичних викликів XXI століття вимагає критичного осмислення досягнутого i зосередження зусиль та ресурсів на розв’язанні найбільш гострих проблем, які стримують розвиток освітньої галузі, не надають змоги забезпечити нову якість освіти, адекватну нинішній історичній епосі. Однією з цих проблем є поступове зниження рівня мовленнєвої 
культури студентів.

Успішне опанування кожної професії неможливе без опанування культури мовлення і культури спілкування. На сьогодні проблема володіння вільним, справді культурним словом $\epsilon$ особливо актуальною і важливою для тих, хто користується словом як основним інструментом своєї професії, передовсім для філологів, педагогів, чиє мовлення не тільки головна зброя у фаховій діяльності, але й зразок свідомо чи несвідомо засвоєний, який сприймається учнями чи студентами. Це питання було предметом дослідження таких провідних вітчизняних науковців, як: С. Караман, Л. Мацько, М. Плющ, О. Пономарів, В. Сухомлинський, І. Ющук та ін.

Зазначимо, що функції та обов’язки викладачів філологічних спеціальностей працівників навчального закладу - вимагають від них постійного самовдосконалення, високої особистісної культури, яка виявляється насамперед у культурі мовлення. Адже без цього вони не зможуть задовольнити різнобічні інтереси та запитання тих кого вони навчають, і завоювати їх довіру, авторитет та повагу. Особистість викладача, культура його поведінки і мовлення впливають на формування особистості кожного учня чи студента, котрих він навчає. Педагогічне керівництво процесом формування культури мовлення учня більшою мірою залежить від культури мовлення викладача, оскільки саме він завжди $є$ еталоном для тих кого він навчає, взірцем для наслідування. Учень усвідомлює не тільки те, чого його навчають, на нього справляє вплив особистість Учителя, манера триматися, уміння спілкуватися з учнями, співробітниками тощо. Авторитет завойовується, формується тільки в результаті цілеспрямованої, наполегливої праці вчителя над собою, над підвищенням педагогічної кваліфікації й майстерності, естетичним самовдосконаленням, розширенням теоретичних знань та світогляду. Тому професійно-педагогічні якості майбутнього вчителя не можна сформувати у відриві від виховання моральності та естетичної спрямованості його особистості. Недоліки естетичного виховання студентів негативно відбиваються на їхньому духовному розвитку, призводять до вияву однобокості в розумінні мистецтва, природи, що й виявляється у відсутності культури мовлення.

Проблема формування мовленнєвої культури студентів набирає популярності в 20-і роки XX ст. завдяки працям Г. Вінокура, В. Чернишова, Л. Щерби. Праці науковців були присвячені виявленню й опису частин мовної системи, що найбільш чутливі до порушення літературної норми, методам підвищення грамотності, розповсюдження знань про мову, виховання поваги до правильного мовлення. Особливу роль відіграли праці В. Виноградова. С. Ожегова, Д. Розенталя, Л. Успенського. У середині 80-х років ХХ ст. виходить 3 друку низка підручників 3 риторики Н. Кохтєва, Ю. Рождественського та ін. В Україні цією проблемою займались О. Аматьєва, Н. Бабич, А. Богуш, М. Ільяш, Г. Олійник, М. Пентилюк, С. Хаджирадєва та ін. Розвиток мовленнєвої культури студентів у вищих закладах освіти України є актуальною проблемою, що потребує активних творчих пошуків та постійно залишається в центрі уваги. Від того, якою мовою звернеться викладач до студента, чи збільшить любов до рідного слова, залежить у подальшому мовний розвиток особистості.

Метою статті є дослідження проблеми формування мовленнєвої культури майбутніх учителів філологічних спеціальностей, з'ясування сутності поняття «культура мовлення».

Мова - історично усталена система звуків, лексики, правил словотворення i словозміни, побудови речень і тексту, якими користуються іï̈ носії для висловлення думок, передачі почуттів. Мова живе в мовленні, без якого вона не може здійснювати свою комунікативну функцію. Проте і мовлення, а відтак мовленнєва комунікативна діяльність, 
неможливі без мови, її словникового складу, фонетичних законів, правил граматики. Це конкретне вираження мовної системи індивідом, «мова в дії».

Мова і культура перебувають в одній поняттєвій площині і як духовні цінності органічно пов'язані між собою. Слово культура (від лат. cultura - догляд, освіта, розвиток) означає сукупність матеріальних і духовних цінностей, які створило людство протягом своєї історії. Мова - це вияв культури. «Мова утримує в одному духовному полі національної культури всіх представників певного народу і на його території, і за її межами. Вона цементує всі явища культури, є їх концентрованим виявом» [2]. Плекаючи мову, дбаючи про ії розвиток, оберігаючи її самобутність, ми зберігаємо національну культуру.

Культура мови - галузь мовознавства, що присвячена утвердженню (кодифікації) норм на всіх мовних рівнях. Використовуючи відомості історії української літературної мови, граматики, лексикології, словотвору, стилістики, культура мови виробляє наукові критерії в оцінюванні мовних явищ, виявля тенденції розвитку мовної системи, проводить цілеспрямовану мовну політику, сприяє втіленню норм у мовну практику. Культура мови має регулювальну функцію, оскільки пропагує нормативність, забезпечує стабільність, рівновагу мови, хоча водночас живить їі, оновлює. Вона діє між літературною мовою і діалектами, народнорозмовною, між усною і писемною формами [3, с. 52].

Культура мовлення передбачає дотримання мовних норм вимови, наголосу, слововживання і побудови висловів, точність, ясність, чистоту, логічну стрункість, багатство і доречність мовлення, а також дотримання правил мовленнєвого етикету. Головним завданням для студента-філолога у процесі професійної підготовки є формування мовленнєвої культури, щоб він умів комунікативно виправдано спілкуватися в будь-якій ситуації, дотримуючись норм літературної мови. Важливість і актуальність такого завдання визначається тим, що в роботі над підвищенням культури мовлення передовсім необхідно орієнтуватися на тих носіїв української мови, які використовують ії як знаряддя спілкування і тому можуть впливати на мовленнєву культуру всього суспільства. Перше місце серед таких носіїв посідають учителі філологічних спеціальностей. Тому важливою $є$ культура мовлення студентів-філологів - майбутніх учителів-словесників та її розвиток.

Але у наш час культурі мовлення студентів-філологів не приділяють належної уваги, хоча вона $є$ мистецтвом удосконалення особистості засобами мови. Зазначимо, що під час формування мовленнєвої культури студентів-філологів необхідно враховувати такі принципи: комунікативного спрямування; комунікативно-педагогічної ситуативності; урахування психофізіологічних та інших індивідуальних особливостей мовця; дотримання вимог, що висуваються до кожного з видів мовленнєвої діяльності (аудіювання, говоріння, читання, письмо); оптимального поєднання групових та індивідуальних форм роботи з урахуванням рівня підготовки та індивідуальних особливостей студентів; професійного спрямування в підготовці молодого спеціаліста [4, с. 3].

Студенту-філологу необхідно постійно здійснювати самоаналіз власного мовлення, щоб уникати помилок. У контексті нашого дослідження схарактеризуємо деякі ознаки того, що мовлення студентів далеке від досконалості, і їм необхідно виправляти власні недоліки: студентів часто просять повторити щойно сказані слова; у них помітний акцент; також втомлюється горло після десятихвилинної розмови; у їх слухачів через деякий час починає блукати погляд, бо вони говорять монотонно; студент втрачає контроль над голосом наприкінці довгого речення; люди звертають увагу на те, що він (часто несвідомо) повторює слівця або фрази типу «гм», «ну», «так», «знаєте», «угу», «так би мовити» тощо; студенти мають звичку зітхати, закусувати губу або виставляти ї̈, цмокати язиком. 
Важливою передумовою ефективності мовленнєвої діяльності майбутнього вчителя $є$ оволодіння їі технікою, компонентами якої є голос, дикція, темп, ритм, інтонація, паузи. Названі компоненти - це своєрідна акустична система «відтворення людини людиною». Вони виконують важливі функції, зокрема створюють імідж людини, сприяють виявленню іiі індивідуальних психічних особливостей, передають емоційний стан мовця.

У системі формування мовленнєвої культури майбутнього вчителя важливо усвідомлювати основні функції, які має виконувати мовлення. Автори навчального посібника «Педагогічна майстерність» за редакцією І. Зязюна виокремлюють такі основні функції педагогічного мовлення: комунікативну - встановлення і регуляція стосунків між учителем і учнями, забезпечення гуманістичної спрямованості розвитку вихованців; психологічну створення умов для забезпечення психічної свободи вихованців, вияву індивідуальних особливостей особистості, зняття соціально-фізіологічних затисків; пізнавальну забезпечення оптимальних умов для сприймання навчального матеріалу учнями, формування в них емоційно-ціннісного ставлення до знань; організаційну - забезпечення раціональної й ефективної пізнавальної діяльності учнів [1].

Отже, формування мовленнєвої культури майбутніх учителів філологічних спеціальностей залежить від таких чинників: по-перше, повинна бути створена цілісна, єдина програма, спрямована на формування культури мовлення студентів-філологів, що пов’язує всі фахові дисципліни: практичний курс української мови, культуру мови, сучасну українську літературну мови, стилістику, риторику тощо. По-друге, повинна розвиватися належним чином самостійна пізнавальна діяльність студентів засобами мови. Також текстові, інформаційні та інші матеріали в підручниках та посібниках з фахових дисциплін повинні більше використовуватись задля розвитку правильного мовлення майбутнього вчителя.

1. Зязюн I. А. Педагогічна майстерність: підручник [Електронний ресурс]/ І. А. Зязюн, Л. В. Крамущенко, І. Ф. Кривонос. - Київ : Вища шк., 1997. - Режим доступу до pecypcy : http://www.ex.ua/5074950. 2. Іванишин В. Я. Мова і нація: тези про місце і роль мови в національному відродженні України / Іванишин В., Радевич-Винницький Я. Дрогобич, 1994. - С. 93-94. 3. Мацюк 3. Українська мова професійного спілкування / 3. Мацюк , Н. Станкевич. - Київ : Каравела, 2005. - 352 с. 4. Окуневич Т. Г. Формування культури мовлення студентів-філологів [Електронний ресурс] / Т. Г. Окуневич. - 2013. Режим доступу: http://ekhsuir.kspu.edu/ bitstream/123456789/637/1 5. Проект Національної стратегії розвитку освіти в Україні на 2012-2021 роки [Електронний ресурс].- Режим доступу : http://www.meduniv. lviv.ua/files/ info/nats_strategia.pdf. 6. Техніка формування мовленнєвої культури вчителя [Електронний ресурс]/ Режим доступу: http://pedlib.com.ua/ tehnika- formuvannya-movlennyevo-kulturi-vchitelya.htm.

УДК 372.882

Оксана Фенцик

\section{ПРОБЛЕМА ВИВЧЕННЯ ЕПІЧНОГО ТВОРУ В ЛІТЕРАТУРНІЙ ОСВІТІ: ІСТОРИКО-МЕТОДИЧНИЙ ОГЛЯД}

Фенцик О. М. Проблема вивчення епічного твору в літературній освіті: історикометодичний огляд.

Статтю присвячено проблемі критичного аналізу методичної спадщини в галузі 